\title{
Suscetibilidade in vitro e in vivo de Pythium insidiosum: estudo comparativo entre acetato de caspofungina e imunoterapia em coelhos*
}

\section{DANIELA ISABEL BRAYER PEREIRA}

\author{
Laerte Ferreiro (Orientador - UFRGS)
}

Janio Morais Santurio (Co-orientador - UFSM)

Banca: Sílvia S. Guterres (UFRGS), Sydney Hartz Alves (UFSM), Mário Carlos Araújo Meireles (UFPel), João Roberto Braga Mello (UFRGS).

O oomiceto aquático Pythium insidiosum, classificado no Reino Stramenipila, é o agente etiológico da pitiose, uma doença crônica, piogranulomatosa, que acomete eqüinos, caninos, felinos, bovinos, ovinos e humanos que habitam regiões tropicais e subtropicais. Diversos protocolos para o tratamento da enfermidade têm sido utilizados, incluindo terapia com antifúngicos, cirurgia e imunoterapia. O presente estudo objetivou avaliar a suscetibilidade in vitro de 27 isolados clínicos de Pythium insidiosum ao acetato de caspofungina, bem como correlacionar os resultados obtidos in vitro com a resposta da terapêutica in vivo e comparar a eficácia de dois tratamentos, acetato de caspofungina e imunoterapia, utilizando coelhos como modelo experimental. Vinte e seis isolados de Pythium insidiosum provenientes de casos clínicos de pitiose em animais no Brasil (24 eqüinos, 01 canino e 01 ovino) e um isolado ATCC (58637) foram avaliados neste estudo. Os testes in vitro foram desenvolvidos utilizando-se a macrotécnica em caldo seguindo o protocolo internacional M38-A do CLSI. O inóculo consistiu de uma suspensão de 2-3×10³ zoósporos de Pythium insidiosum diluído 1:10 em caldo RPMI. As concentrações finais do acetato de caspofungina variaram de $0,25-128 \mu \mathrm{g} / \mathrm{mL}$. A leitura dos CIMs foi visual, considerando-se o crescimento ou não de hifas em 24 horas de incubação a $37^{\circ} \mathrm{C}$, sendo adotados 3 critérios de leitura: CIM0; CIM1 e CIM2 ( $100 \%, 90 \%$ e $50 \%$ de inibição de crescimento, respectivamente), assim como também foi determinada a concentração fungicida mínima. No ensaio in vivo, 15 coelhos inoculados subcutaneamente com 20.000 zoósporos de Pythium insidiosum foram divididos em 3 grupos de 5 animais (grupo 1, controle; grupo 2, tratado com imunoterápico Pitium Vac® e grupo 3, tratado com acetato de caspofungina). Os tratamentos iniciaram-se 25 dias após a inoculação e consitiram de: 1) 8 doses de imunoterápico administradas em intervalos de 14 dias; 2) $1 \mathrm{mg} / \mathrm{kg} /$ dia de acetato de caspofungina durante 20 dias consecutivos. Dezoito semanas após o início do experimento, os animais foram necropsiados e fragmentos de lesões foram coletados para análise histopatológica e morfométrica. Quatorze isolados (51,8\%) evidenciaram CIM0 de $64 \mu \mathrm{gg} / \mathrm{mL}$ e 24 (88,8\%) CIM1 com variação de $=8 \mu \mathrm{g} / \mathrm{mL}$ a $64 \mu \mathrm{g} / \mathrm{mL}$. Na determinação da concentração fungicida mínima, 17 (62,9\%) amostras requereram $64 \mu \mathrm{g} / \mathrm{mL}$. Os animais de ambos os tratamentos apresentaram redução da área de lesões, quando comparados aos animais do grupo controle $(\mathrm{P}<0.05)$. As áreas de lesões dos coelhos tratados com acetato de caspofungina evidenciaram redução durante o tratamento, porém rapidamente retornaram a progredir quando a administração do fármaco foi suspensa. O aspecto histológico das lesões foi similar entre os grupos estudados e a avaliação morfométrica evidenciou que os animais dos grupos 2 e 3 apresentaram menor quantidade de hifas nas áreas de necrose $(\mathrm{P}<0.05)$. Os resultados obtidos evidenciam que, embora não tenha havido diferença entre os tratamentos avaliados, a imunoterapia, em função de seu custo, continua sendo a melhor alternativa para o tratamento da pitiose. A ocorrência de altas CIMs associada a falta de atividade fungicida do acetato de caspofungina observados neste estudo, sugerem que Pythium insidiosum é pouco suscetível a este antifúngico.

Descritores: Pythium insidiosum, oomiceto, pitiose, acetato de caspofungina, imunoterapia, Pitium Vac, coelho.

*Tese de Doutorado n. 86 (Especialidade: Micologia) 117f. Programa de Pós-Graduação em Ciências Veterinárias [www.ufrgs.br/ppgcv], Faculdade de Veterinária, Universidade Federal do Rio Grande do Sul (UFRGS), Porto Alegre/RS. CORRESPONDÊNCIA: D.I.B.Pereira [danielabrayer@gmail.com] 


\title{
In vitro and in vivo susceptibility of Pythium insidiosum: comparison study between caspofungin acetate and immunitherapy in experimental pythiosis in rabbits **
}

\author{
DANIELA ISABEL BRAYER PEREIRA
}

Laerte Ferreiro (Adviser - UFRGS)

Janio Morais Santurio (Co-adviser - UFSM)

Committee: Sílvia S. Guterres (UFRGS), Sydney Hartz Alves (UFSM), Mário Carlos Araújo Meireles (UFPel), João Roberto Braga Mello (UFRGS).

Pythium insidiosum is an oomycete classified in the Kingdom Stramenipila. It causes pythiosis, a chronic, difficultto-treat, pyogranulomatous disease that affects mainly horses, but can also affect dogs, cats, cattle, sheep and humans that inhabit tropical and subtropical regions. Several protocols to treat pythiosis have been used, including antifungal drug administration, surgery and immunotherapy. The present study aimed to evaluate the in vitro susceptibility of 27 Pythium insidiosum clinical isolates to caspofungin acetate, as well as to relate the results obtained in vitro with the response of in vivo therapy, and to assess the efficacy of two treatments, immunotherapy and caspofungin acetate administration, in rabbits with experimental pythiosis. Twenty-six samples of Pythium insidiosum isolated from pythiosis lesions from animals in Brazil (24 horses, $01 \mathrm{dog}$ and 01 sheep) and one ATCC isolate (58637) were studied. The in vitro tests were performed using the broth macrodilution method following the CLSI M38-A protocol. The inoculum consisted of a suspension containing 2-3x10 3 Pythium insidiosum zoospores diluted 1:10 with RPMI broth. The final concentrations of caspofungin acetate were $0.25-128$ $\mu \mathrm{g} / \mathrm{mL}$. The MICs were read after $24 \mathrm{~h}$ of incubation at $37^{\circ} \mathrm{C}$. The reading was visual and assessed the growth or absence of growth of hyphae. Three MIC reading criteria were adopted: MIC0, MIC1 and MIC2 (growth inhibition of 100\%, 90\% and $50 \%$, respectively). The minimum fungicidal concentration was also determined. For the in vivo assay, fifteen rabbits were subcutaneously inoculated with 20,000 Pythium insidiosum zoospores and were divided into 3 groups of 5 animals (group 1, control; group 2, treated with Pitium Vac ${ }^{\circledR}$ immunotherapic; and group 3, treated with caspofungin acetate). The treatments were started 25 days after the inoculation, and consisted of: 1) 8 doses of the immunotherapic administered at 14-day intervals; and 2) $1 \mathrm{mg} / \mathrm{kg} / \mathrm{day}$ of caspofungin acetate during 20 consecutive days. The animals were necropsied eighteen weeks after the start of the experiment, and lesion fragments were collected for histopathologic and morphometric analyses. Fourteen isolates (51.8\%) had an MIC0 of $64 \mu \mathrm{g} / \mathrm{mL}$, and $24(88.8 \%)$ had an MIC1 that varied between $=8 \mu \mathrm{g} / \mathrm{mL}$ and $64 \mu \mathrm{g} / \mathrm{mL}$. When subjected to the minimum fungicidal concentration assay, 17 (62.9\%) samples required $64 \mu \mathrm{g} / \mathrm{mL}$. The animals in both treatment groups displayed smaller lesion sizes compared to the animals of group control $(\mathrm{P}<0.05)$. The subcutaneous lesion areas of rabbits treated with caspofungin acetate exhibited a reduction in their progression during the treatment. However, lesions quickly resumed growth when the administration of the drug was suspended. The histological aspect of the lesions was similar between the groups under study, and the morphometric evaluation showed that the animals in groups 2 and 3 had lower amounts of hyphae in necrotic areas $(\mathrm{P}<0.05)$. The results obtained indicate that, even though the treatments did not differ significantly, the immunotherapic treatment is still the best alternative to treat pythiosis. In addition, the high MICs and lack of fungicidality of caspofungin acetate suggest that Pythium insidiosum is poorly susceptible to this antifungal drug.

Keywords: Pythium insidiosum, oomycete, pythiosis, caspofungin acetate, immunotherapy, Pitum Vac, rabbits.

Presented: 31 January 2008

\footnotetext{
**Doctoral Dissertation \# 86 (Field: Mycology) 117p. Graduate Program in Veterinary Sciences [www.ufrgs.br/ppgcv], Faculdade de Veterinária, Universidade Federal do Rio Grande do Sul (UFRGS). Porto Alegre/ Brazil. CORRESPONDENCE: D.I.B. Pereira [danielabrayer@gmail.com]
} 